\title{
PENGARUH PENERAPAN SISTEM INFORMASI AKUNTANSI (SIA) TERHADAP KINERJA PERUSAHAAN (STUDI EMPIRIS PADA UMKM DI KOTA BANDA ACEH)
}

\author{
T.Irzal Rizki Mauliansyah* ${ }^{* 1}$, Mulia Saputra ${ }^{* 2}$ \\ ${ }^{1,2}$ Program Studi Akuntansi Fakultas Ekonomi dan Bisnis Universitas Syiah Kuala \\ e-mail: dekpon94@ymail.com ${ }^{* 1}$, mulia_1@ unsyiah.ac.id ${ }^{* 2}$
}

\begin{abstract}
This study aims to determine the effect of utilization, quality, security and supporting facilities of Accounting Information Systems (SIA) on the performance of micro, small and medium enterprises. The research sample was taken by a number of MSMEs in Banda Aceh which engaged in the industry, trade and various services sectors with a total sample of 88 MSMEs. The results of the study show that: (1) The utilization, quality, safety and supporting facilities of Accounting Information Systems (SIA) together have a significant effect on company performance; (2) Utilization of Accounting Information Systems (AIS) has a significant effect on company performance; (3) Quality of Accounting Information System (SIA) has a significant effect on company performance, (4) Security of Accounting Information Systems (SIA) has a significant effect on company performance, and (5) Supporting tools of Accounting Information Systems (SIA) have a significant effect on company performance.
\end{abstract}

Keywords: Accounting Information System, Utilization, Quality, Security, Supporting Facilities for SIA, UMKM.

\section{Pendahuluan}

Usaha Mikro, Kecil dan Menengah (UMKM) adalah organisasi yang menempatkan kepentingan dan kesejahteraan anggota di pusat kegiatan koperasi secara keseluruhan, bahkan banyak koperasi yang fokus pada faktor keuangan dalam kegiatan mereka. Jadi pada bagian pelanggan dan karyawan sedikit terabaikan. Konsep balanced scorecard diperkenalkan untuk membantu perusahaan mempelajari hasil pencapaian dalam empat aspek.

Pengembangan Usaha Mikro, Kecil dan Menengah di Aceh menghadapi berbagai kendala untuk meningkatkan produktivitas, termasuk keterbatasan akses ke modal, yang menghasilkan peningkatan kualitas produk. Dalam wawancara dengan media cetak, pejabat gubernur Aceh Nova Iriansyah mengatakan bahwa peningkatan saat ini dalam jumlah usaha Mikro, Kecil dan Menengah (UMKM) di Aceh tidak disertai dengan peningkatan produktivitas. Salah satu hambatan yang dihadapi pengusaha UMKM adalah akses ke modal.

Usaha Mikro, Kecil dan Menengah (UMKM) di Aceh juga dianggap sulit untuk dikembangkan karena terbatasnya akses ke sumber daya produktif, terutama dalam bahan mentah, kapasitas dan infrastruktur yang terbatas, serta informasi pasar dan kompetensi wirausaha yang rendah. Meskipun jumlah usaha kecil dan menengah di Banda Aceh terus bertambah, sektor ini tidak dikembangkan secara optimal dalam hal produktivitas dan kebutuhan untuk bekerja keras untuk meningkatkan kualitas UMKM.

Dalam hal kuantitas, jumlah UMKM di Aceh, terutama di Banda Aceh, terus meningkat, seperti yang ditunjukkan pada tabel berikut.

Tabel 1

Peningkatan Jumlah UMKM di Kota Banda Aceh dari Tahun 2016-2018.

\begin{tabular}{|l|l|c|r|r|}
\hline \multirow{2}{*}{ No. } & \multirow{2}{*}{ Sektor UMKM } & \multicolumn{3}{|c|}{ Jumlah } \\
\cline { 3 - 5 } & & $\mathbf{2 0 1 6}$ & $\mathbf{2 0 1 7}$ & $\mathbf{2 0 1 8}$ \\
\hline 1 & Industri & 279 & 831 & 941 \\
\hline 2 & Perdagangan & 242 & 373 & 580 \\
\hline 3 & Jasa & 120 & 161 & 493 \\
\hline \multicolumn{2}{|c|}{ Jumlah } & $\mathbf{6 4 1}$ & $\mathbf{1 . 3 6 5}$ & $\mathbf{2 . 0 1 4}$ \\
\hline
\end{tabular}

Berdasarkan tabel 1.1, dapat dijelaskan bahwa sejak tahun 2016 sampai saat ini terlihat peningkatan pertumbuhan UMKM di Kota Banda Aceh yang signifikan dimana sejak tahun 2016 yang hanya berjumlah 641 UMKM yang terbagi ke dalam sektor usaha industry, perdagangan dan jasa kemudian mengalami peningkatan menjadi 1.365 UMKM dan di tahun 2018 bertambah hampir dua kali lipatnya yaitu sebanyak 2.014 UMKM. 
Data yang diperoleh dari Dinas Kop-UKM Aceh, fenomena dan permasalahan yang dapat dilihat bahwa bentuk usaha kecil dan menengah (UMKM) tersebut cenderung adalah usaha perseorang dengan lingkup bisnis usaha yang kecil dan terbatas dan hanya mempekerjakan rata-rata 2 hingga 3 orang pekerja. Dengan lingkup usaha yang terbatas dan cenderung merupakan usaha rumahan tentunya peran Sistem Informasi Akuntansi dalam menyiapkan laporan keuangan dan non-keuangan untuk kebutuhan manajerial dalam upaya evaluasi perusahaan tidaklah begitu penting apalagi tidak didukung oleh sarana pendukung yang memadai.

Penggunaan teknologi informasi yang tepat yang terkait dengan penerapan sistem informasi akuntansi pada perusahaan dapat meningkatkan produktivitas perusahaan. Namun kemajuan yang menakjubkan dalam teknologi telah membuka kemungkinan untuk menghasilkan dan menggunakan informasi akuntansi dari sudut pandang strategis. Karena hal ini penting bagi semua perusahaan, terutama untuk usaha kecil dan menengah yang membutuhkan informasi akuntansi untuk berurusan dengan tingkat ketidakpastian yang lebih tinggi di pasar yang kompetitif (El-Louadi, 2008).

Beberapa dimensi yang terkait dengan Sistem Informasi Akuntansi (SIA) antara lain meliputi: pemanfaatan SIA, kualitas SIA, keamanan SIA dan sarana pendukung. Fenomena yang dapat dilihat sejauh ini dari aspek pemanfaatan sebagian besar UMKM yang ada di Kota Banda Aceh masih belum menggunakan Sistem Informasi Akuntansi untuk mengelola dan mengolah laporan keuangan dan nonkeuangan yang dibutuhkan. Sejumlah UMKM tersebut cenderung masih menggunakan pelaporan manual yang independen dan tidak saling terintegrasi satu dengan yang lainnya sehingga akan menyulitkan dalam proses update dan perubahan data yang tidak dapat dilakukan secara otomatis.

\section{Kerangka Teori}

Gelinas \& Dull (2012:16) berpendapat bahwa sistem informasi akuntansi adalah subsistem spesialisasi sistem informasi untuk mengumpulkan, memproses dan menyajikan informasi yang berkaitan dengan aspek keuangan peristiwa bisnis. Sejalan dengan itu, Hall (2013:8) menjelaskan bahwa sistem informasi akuntansi adalah subsistem dari proses keuangan dan operasi non-keuangan yang secara langsung mempengaruhi pemrosesan transaksi keuangan.

Lebih lanjut, Hall (2013:9) mengklaim bahwa sistem informasi akuntansi keuangan terdiri dari tiga subsistem utama:

1) Sistem pemerosesan transaksi

Sistem pemrosesan transaksi adalah sistem yang mendukung transaksi bisnis harian dengan berbagai laporan, dokumen, dan pesan untuk pengguna di seluruh organisasi.

2) Buku besar/sistem pelaporan keuangan

Sistem informasi akuntansi menghasilkan laporan keuangan tradisional, seperti laporan laba rugi, neraca, laporan arus kas, laporan pajak dan laporan lainnya yang diharuskan oleh hukum.

3) Manajemen sistem pelaporan

Sistem informasi akuntansi menyediakan manajemen internal untuk laporan keuangan tujuan khusus dan informasi yang diperlukan untuk pengambilan keputusan, seperti anggaran, laporan varians dan laporan akuntabilitas.

Dapat disimpulkan bahwa Sistem Informasi Akuntansi adalah sistem komputer yang mengumpulkan, mendaftar, menyimpan dan memproses data dari operasi akuntansi biasa. Tujuannya adalah untuk menghasilkan informasi akuntansi dan keuangan yang akan berguna bagi pihak internal dan eksternal untuk membuat keputusan dan dapat diperhitungkan.

Rama \& Jones (2013:7) menyebutkan bahwa terdapat lima jenis tujuan pemakai informasi akuntansi:

1) Membuat laporan eksternal

Perusahaan menggunakan sistem informasi akuntansi untuk menghasilkan laporan-laporan khusus untuk memenuhi kebutuhan informasi dari para investor, kreditor, dinas pajak, badan-badan pemerintah, dan yang lain. Laporan-laporan ini mencakup laporan keuangan, Surat Pemberitahuan (SPT) pajak, dan laporan yang diperlukan oleh badan-badan pemerintah yang mengatur perusahaan dalam industri perbankan dan utilitas.

2) Mendukung aktivitas rutin

Para manajer memerlukan satu sistem informasi akuntansi untuk menangani aktivitas operasi rutin sepanjang siklus operasi perusahaan. 
3) Mendukung pengambilan keputusan

Informasi juga diperlukan untuk mendukung pengambilan keputusan yang tidak rutin pada semua tingkat dari suatu organisasi. Contohnya antara lain mengetahui produk-produk yang penjualannya bagus dan pelanggan mana yang paling banyak melakukan pembelian. Informasi ini sangat penting untuk merencanakan produk baru, memutuskan produk apa yang harus tersedia dan menjual produk kepada pelanggan.

4) Perencanaan dan pengendalian

Sistem informasi juga diperlukan untuk merencanakan dan mengendalikan kegiatan. Informasi anggaran dan biaya standar disimpan dalam sistem informasi, dan laporan dirancang untuk membandingkan angka-angka anggaran dengan jumlah aktual.

5) Menerapkan pengendalian internal

Pengendalian internal meliputi kebijakan, prosedur, dan sistem informasi yang digunakan untuk melindungi aset perusahaan dari kehilangan atau korupsi, serta untuk menjaga keakuratan data keuangan.

Romney (2012:3) menyebutkan adalah, sistem informasi akuntansi mempunyai tiga fungsi penting dalam organisasi, yaitu:

1. Kumpulkan dan simpan data tentang kegiatan yang dilakukan oleh organisasi,sumber daya yang dipengaruhi oleh sumber daya ini,dan peserta yang terlibat dalam berbagai tindakan sehingga manajemen,karyawan dan pihak berkepentingan lainnya dapat meninjau hal-hal yang telah terjadi.

2. Mengubah data menjadi informasi yang berguna bagi pihak manajemen untuk membuat keputusan dalam aktivitas perencanaan, pelaksanaan, dan pengawasan.

3. Menyediakan pengendalian yang memadai untuk menjaga aset-aset organisasi, termasuk data organisasi, untuk memastikan bahwa data tersebut tersedia saat dibutuhkan, akurat dan handal.

American Institute of Certified Public Accountants (AICPA), menyebutkan bahwa sistem informasi akuntansi memiliki lima tujuan utama, sebagaimana yang dikemukakan oleh Romney (2012:249) antara lain:

1. Mengidentifikasi dan mencatat semua transaksi yang valid.
2. Mengklasifikasi transaksi secara tepat.

3. Mencatat transaksi pada nilai moneter yang tepat.

4. Mencatat transaksi dalam periode akuntansi yang tepat.

5. Menampilkan secara tepat semua transaksi dan pengungkapan berkaitan dengan laporan keuangan.

Dengan demikian, dapat dijelaskan bahwa tujuan utama dari Sistem Informasi Akuntansi (SIA) adalah mencatat, memproses, menyimpan, meringkas, dan mengkomunikasikan informasi atas suatu organisasi. Hal ini dapat berarti bahwa akuntan harus memahami bagaimana: (1) transaksi diawali; (2) data diubah dari dokumen sumber ke bentuk yang dapat dibaca mesin; (3) file komputer diperbarui; (4) data diproses untuk mempersiapkan suatu informasi; dan (5) informasi dilaporkan ke para pemakai internal dan pihak eksternal.

Diharapkan dengan aplikasi ini, sistem informasi akuntansi dapat mendukung operasi perusahaan, memastikan efisiensi dan efektivitas yang akan menguntungkan perusahaan.

\section{Penggunaan Sistem Informasi Akuntansi}

Penggunaan sistem informasi akuntansi dapat dilakukan sesuai dengan jenis kegiatan perusahaan, yang dibagi menjadi beberapa subsistem Sistem Informasi Akuntansi, yaitu (Hall, 2009):

1) Sistem pemrosesan transaksi (Transaction Processing System-TPS)

2) Sistem buku besar atau pelaporan keuangan (General ledger or Financial Reporting SystemGL/FRS)

3) Sistem pelaporan manajemen (Management Reporting System-MRS)

Hasil yang dapat diperoleh dengan menggunakan sistem informasi akuntansi adalah informasi. Informasi adalah data yang telah dipesan dan diproses agar masuk akal (Romney \& Steinbart, 2011). Sumber informasi dengan karakteristik yang relevan dan tepat waktu memiliki dampak signifikan pada efisiensi manajemen, sedangkan karakteristik lainnya, seperti dapat diandalkan, lengkap, dapat dimengerti dan dapat diperiksa lagi,tidak mempengaruhi efisiensi manajemen.

Penggunaan sistem informasi akuntansi dapat dilihat dari keberadaan komputer, perangkat lunak dan 
jaringan internet. Proses akuntansi dapat didukung menggunakan perangkat lunak akuntansi yang tersedia di komputer perusahaan. (Widyaningtyas, 2013). Ini adalah komponen awal untuk menerapkan sistem informasi akuntansi terkomputerisasi dalam suatu perusahaan. Kemudian, dengan bantuan komputer, perangkat lunak, dan Internet, proses akuntansi, seperti proses transaksi dan akuntansi persediaan, dilakukan.

\section{Kualitas Sistem Informasi Akuntansi}

Variabel kualitas sistem informasi akuntansi berasal dari pengukuran yang terdapat dalam model keberhasilan sistem informasi D \& M. Kualitas sistem dan kualitas informasi yang diterima akan menentukan bagaimana pengguna menggunakan dan memenuhi penerapan sistem informasi akuntansi di perusahaan. Maka itu akan mempengaruhi kinerja orang tersebut, dan selanjutnya akan mempengaruhi kinerja perusahaan (Jones \& Dasaratha, 2008).

Kualitas sistem informasi akuntansi mengacu pada kualitas perangkat lunak yang digunakan di perusahaan. Memiliki perangkat lunak yang andal dapat menyederhanakan proses akuntansi sebagai tambahan untuk menggunakan komputer. Beberapa kriteria perangkat lunak yang dapat digunakan di perusahaan mudah dipahami dan dapat meningkatkan relevansi, akurasi, singkatnya, kelengkapan, dan ketepatan waktu laporan perusahaan (Romney, 2012). Salah satu program yang paling umum digunakan adalah Microsoft Excel. Perangkat lunak ini memiliki fitur sederhana yang non-profesional dapat dengan mudah digunakan tanpa pelatihan khusus.

Sistem informasi akuntansi yang berkualitas seperti yang dijabarkan oleh Garvin (2008) dapat dibagi ke dalam beberapa dimensi antara lain sebagai berikut:

1) Performance (kinerja), menyangkut karakteristik utama sebuah produk

2) Feature (fitur), fungsi tambahan dari fungsi utama suatu produk

3) Reliability (kehandalan), menyangkut kehandalan suatu produk.

4) Conformance (kesesuaian), tingkat dimana suatu desain produk dan karakteristik memenuhi standar yang ditentukan sebelumnya.

5) Durability (ketahanan), mengukur umur produk.

6) Serviceability (kemudahan perbaikan), kemudahan perbaikan ketika dibutuhkan.
7) Aesthetic (estetika/keindahan), menyangkut penampilan produk

8) Perceived quality, kualitas yang diterima konsumen.

\section{Keamanan Sistem Informasi Akuntansi}

Teknologi ini terus berkembang dan menghasilkan berbagai penemuan bermanfaat yang memfasilitasi setiap kegiatan perusahaan. Namun demikian, berbagai prestasi disertai dengan berbagai ancaman yang takut merusak sistem informasi akuntansi. Keamanan sistem informasi akuntansi kini telah menjadi masalah dan arah utama. Beberapa indikator yang terkait dengan keamanan sistem informasi akuntansi, antara lain: bencana alam, kesalahan software, dan beberapa hal yang terkait dengan tindakan ketidaksengajaan maupun sengaja. (Garvin, 2008).

Titisari (2015) mengatakan teknologi yang baik dan dapat diandalkan dianggap aman bagi penggunanya. Keamanan sistem adalah bagian dari sistem kualitas, yang akan mempengaruhi kepuasan pengguna dengan sistem informasi akuntansi. Sistem informasi akuntansi keamanan akan mempengaruhi data yang terkandung dalam informasi yang dihasilkan. Dengan demikian, kualitas informasi menjadi diragukan jika tidak ada perlindungan dalam sistem informasi akuntansi.

\section{Sarana Pendukung Sistem Informasi Akuntansi}

Diharapkan bahwa sistem informasi akuntansi akan dapat memberikan informasi keuangan atau nonkeuangan secara akurat dan tepat waktu. Untuk meningkatkan manfaat dari penggunaan sistem informasi akuntansi, alat bantu tambahan digunakan. Alat Pendukung Sistem Informasi Diyakini bahwa akuntansi penting untuk meningkatkan efisiensi penerapan sistem informasi akuntansi. Diharapkan, dengan dukungan sistem informasi akuntansi, sistem informasi akuntansi dapat memberikan manfaat optimal bagi perusahaan.

Berikut akan dijelaskan beberapa indikator terkait dengan sarana pendukung Sistem Informasi Akuntansi (SIA) yaitu: ketersediaan ruangan, ketersediaan perangkat komputer dan teknologi serta jaringan online (internet) sebagai pendukung untuk sistem banyak pengguna (multiuser).

Beberapa perusahaan tidak menggunakan komputer dan sistem komputer. Ini dapat dilakukan oleh komputer dan perangkat lunak dalam kategori alat 
bantu dalam penerapan sistem informasi akuntansi. Kehadiran lingkungan kerja yang nyaman juga dapat mempengaruhi efisiensi penggunaan sistem akuntansi informasi. Salah satu contoh adalah ketersediaan ruang yang cukup untuk sistem, serta kenyamanan dan ketepatan ruangan, yang dapat memberikan motivasi atau antusiasme tambahan bagi pekerjaan karyawan untuk meningkatkan pekerjaan mereka (Titisari, 2015).

Menurut Standar Akuntansi Keuangan (2007:18) pengertian kinerja perusahaan terkait dengan tujuan laporan keuangan, yaitu: "Penghasilan bersih (laba) seringkali digunakan sebagai ukuran kinerja atau sebagai dasar bagi ukuran yang lain seperti imbalan investasi (return on investement) atau penghasilan per saham (earnings per share)".

Berdasarkan pengertian-pengertian di atas, dapat ditarik kesimpulan bahwa kinerja perusahaan adalah hasil dari pemanfaatan secara baik atas sumber daya yang ada dan sekaligus mencerminkan seberapa jauh sebuah keberhasilan tercapai atau hasil kerja secara kuantitas dan kualitas yang dicapai oleh seorang manajer dalam melaksanakan tugasnya sesuai tanggung jawab yang diberikan kepadanya.

\section{Metode Penelitian}

\section{Sampel dan Data}

Pengambilan sampel dalam penelitian hanya mengacu kepada UMKM yang sudah menerapkan sistem informasi akuntansi yaitu sebanyak 350 UMKM. Dikarenakan jumlah populasi yang besar, maka teknik penentuan sampel menggunakan rumus yang di kemukakan Slovin

Dengan demikian jumlah sampel dalam penelitian ini adalah sebanyak 88 UMKM yang terdapat di Kota Banda Aceh yang sudah menerapkan Sistem Informasi Akuntansi (SIA).

Tabel 2

Jumlah Sampel Untuk Setiap Sektor Usaha

\begin{tabular}{|c|l|c|}
\hline No. & \multicolumn{1}{|c|}{ Sektor Usaha } & Jumlah \\
\hline 1. & Sektor Industri & 30 UMKM \\
\hline 2. & Sektor Perdagangan & 30 UMKM \\
\hline 3. & Sektor Aneka Jasa & 28 UMKM \\
\hline \multicolumn{2}{|c|}{ Jumlah } & 88 UMKM \\
\hline
\end{tabular}

Sumber: Hasil Observasi, 2019

\section{Operasionalisasi Variabel}

Beberapa dimensi yang tercakup dalam variabel sistem informasi akuntansi meliputi: pemanfaatan SIA, kualitas SIA, keamanan SIA, dan sarana pendukung.
Sedangkan variabel kinerja manajerial meliputi aspek: perencanaan, investigasi, koordinasi, evaluasi, pengawasan, pengaturan staff (staffing), negosiasi, dan perwakilan.

\section{Metode Analisis}

\section{Uji Validitas dan Reliabilitas}

Tes validitas digunakan untuk mengukur validitas atau validitas kuesioner. Sebuah kuesioner yang valid jika kuesioner tersebut mampu mengekspresikan sesuatu yang diukur dan dikorelasikan dengan setiap pernyataan dengan penilaian umum konstruksi dengan tingkat signifikansi 0,01 atau 0,05 (Ghozali, 2011:68).

Sebuah kuesioner menjadi reliabel apabila jawaban informan terhadap pertanyaan yang ada pada kuesioner memberikan jawaban yang konsisten. Pengujian reliabilitas diukur berdasarkan nilai yang dihasilkan pada Cronbach Alpha masing-masing instrumen. Kuesioner dikatan reliabel jika memiliki nilai Cronbach Alpha lebih besar dari 0,60 (Ghozali, 2013:47).

\section{Uji Hipotesis}

Pada penelitian ini, pengujian hipotesis menggunakan metode analisis regresi berganda. Dengan persamaan sebagai berikut:

$$
\begin{aligned}
Y= & a+b_{1} X_{1}+b_{2} X_{2}+b_{3} X_{3}+b_{4} X_{4}+e \\
\text { Dimana: } & \\
Y= & \text { Variabel kinerja UMKM } \\
a= & \text { Konstanta } \\
b= & \text { Koefisien regresi parsial } \\
X= & \text { Variabel penerapan sistem informasi akuntansi } \\
& \text { yang meliputi: pemanfaatan SIA, kualitas SIA, } \\
& \text { keamanan SIA, dan sarana pendukung } \\
e= & \text { Nilai error }
\end{aligned}
$$

Menurut Ghozali (2013:177) pengujian hipotesis secara simultan (Uji F) digunakan untuk melihat pengaruh yang dihasilkan oleh variabel independen terhadap variabel dependen secara bersamaan.

Uji statistik $\mathrm{t}$ dilakukan untuk mengetahui pengaruh yang dihasilkan masing-masing variabel bebas terhadap variabel terikat (Ghozali, 2013:178). 


\section{Hasil Dan Pembahasan}

\section{Variabel Pemanfaatan SIA}

Untuk mengetahui tanggapan responden terhadap variabel Pemanfaatan Sistem Informasi Akuntansi untuk setiap item pertanyaan kuesioner penelitian dapat dilihat pada tabel berikut.

Tabel 4.1

Tanggapan Responden untuk Variabel Pemanfaatan SIA

\begin{tabular}{|c|l|c|c|c|c|c|c|c|}
\hline No & \multicolumn{1}{|c|}{ Pertanyaan } & STS & TS & KS & S & SS & $\begin{array}{c}\text { Rata- } \\
\text { rata }\end{array}$ & $\begin{array}{c}\text { Total } \\
\text { Skor }\end{array}$ \\
\hline 1. & $\begin{array}{l}\text { Ketersediaan Sistem Informasi } \\
\text { Akuntansi yang reliabel sangat } \\
\text { membantu dalam upaya untuk } \\
\text { mengambil kebijakan perusa- } \\
\text { haan }\end{array}$ & 0 & 0 & 31 & 49 & 8 & 3,74 & 329 \\
\hline 2. & $\begin{array}{l}\text { Sistem Informasi Akuntansi } \\
\text { yang digunakan menyajikan } \\
\text { data yang lengkap }\end{array}$ & 0 & 4 & 44 & 23 & 17 & 3,60 & 317 \\
\hline 3. & $\begin{array}{l}\text { Sistem Informasi Akuntansi } \\
\text { yang digunakan mudah dime- } \\
\text { ngerti dan diaplikasikan }\end{array}$ & 0 & 2 & 28 & 32 & 26 & 3,93 & 346 \\
\hline 4. & $\begin{array}{l}\text { Data yang disajikan SIA dapat } \\
\text { dengan mudah diperiksa dan } \\
\text { diuji kembali }\end{array}$ & 0 & 3 & 35 & 39 & 11 & 3,66 & 322 \\
\hline & & & & & & & 1314 \\
\hline
\end{tabular}

Sumber: Data Diolah, 2019

\section{Variabel Kualitas SIA}

Untuk mengetahui tanggapan responden terhadap variabel Kualitas Sistem Informasi Akuntansi untuk setiap item pertanyaan pada kuesioner penelitian dapat dilihat pada tabel sebagai berikut.

\section{Tabel 4.2}

Tanggapan Responden untuk Variabel Kualitas SIA

\begin{tabular}{|c|c|c|c|c|c|c|c|c|}
\hline No & Pertanyaan & STS & TS & KS & $\mathbf{S}$ & SS & $\begin{array}{c}\text { Rata- } \\
\text { rata }\end{array}$ & $\begin{array}{l}\text { Total } \\
\text { Skor }\end{array}$ \\
\hline 1. & $\begin{array}{l}\text { Laporan yang disajikan SIA } \\
\text { memiliki tingkat performance } \\
\text { yang baik dan sesuai harapan. }\end{array}$ & 0 & 0 & 29 & 36 & 88 & 3,93 & 346 \\
\hline 2. & $\begin{array}{l}\text { Sistem Informasi Akuntansi } \\
\text { memiliki fitur yang lengkap } \\
\text { sesuai kebutuhan }\end{array}$ & 0 & 0 & 14 & 39 & 35 & 4,24 & 373 \\
\hline 3. & $\begin{array}{l}\text { Sistem Informasi Akuntansi } \\
\text { menyajikan laporan yang handal }\end{array}$ & 0 & 0 & 22 & 26 & 40 & 4,20 & 370 \\
\hline 4. & $\begin{array}{l}\text { Laporan yang dihasilkan dari } \\
\text { SIA sudah sesuai. }\end{array}$ & 0 & 0 & 14 & 30 & 44 & 4,34 & 382 \\
\hline 5. & $\begin{array}{llr}\text { Sistem } & \text { Informasi } & \text { Akuntansi } \\
\text { yang } & \text { digunakan } & \text { mampu } \\
\text { menampung data dengan baik. }\end{array}$ & 0 & 0 & 20 & 29 & 39 & 4,22 & 371 \\
\hline 6. & $\begin{array}{l}\text { Disfungsi } \text { Sistem Informasi } \\
\text { Akuntansi dapat dengan mudah } \\
\text { ditangani dan tetap menjaga } \\
\text { akurasi data }\end{array}$ & 0 & 0 & 14 & 22 & 52 & 4,43 & 390 \\
\hline 7. & $\begin{array}{ll}\text { Aplikasi } & \text { Sistem } \quad \text { Informasi } \\
\text { Akuntansi } & \text { memiliki tampilan } \\
\text { yang menarik dan indah }\end{array}$ & 0 & 0 & 16 & 23 & 49 & 4,38 & 385 \\
\hline 8. & $\begin{array}{ll}\text { Pengguna memiliki } & \text { persepsi } \\
\text { yang baik terhadap } & \text { Aplikasi } \\
\text { SIA yang diterapkan } & \end{array}$ & 0 & 0 & 14 & 46 & 28 & 4,16 & 366 \\
\hline & & & & & & & & 2983 \\
\hline
\end{tabular}

\section{Variabel Keamanan SIA}

Untuk mengetahui tanggapan responden terhadap variabel Keamanan Sistem Informasi Akuntansi untuk setiap item pertanyaan pada kuesioner penelitian dapat dilihat pada tabel sebagai berikut.

Tabel 4.3.

Tanggapan Responden untuk Variabel Keamanan SIA

\begin{tabular}{|c|l|c|c|c|c|c|c|c|}
\hline No & Pertanyaan & STS & TS & KS & S & SS & $\begin{array}{c}\text { Rata- } \\
\text { rata }\end{array}$ & $\begin{array}{c}\text { Total } \\
\text { Skor }\end{array}$ \\
\hline 1. & $\begin{array}{l}\text { Sistem Informasi Akuntansi } \\
\text { ditempatkan pada tempat yang } \\
\text { cenderung aman dari musibah } \\
\text { bencana alam seperti banjir } \\
\text { dan dapat dibackup setiap saat }\end{array}$ & 0 & 0 & 46 & 40 & 2 & 3,50 & 308 \\
\hline 2. & $\begin{array}{l}\text { Aplikasi SIA memiliki fungsi } \\
\text { dan fasilitas untuk mencegah } \\
\text { kerusakan software dan data }\end{array}$ & 0 & 3 & 70 & 12 & 3 & 3,17 & 279 \\
\hline 3. & $\begin{array}{l}\text { Aplikasi SIA dapat mencegah } \\
\text { kesalahan tindakan pengguna } \\
\text { yang tidak disengaja }\end{array}$ & 0 & 2 & 72 & 14 & 0 & 3,14 & 276 \\
\hline 4. & $\begin{array}{l}\text { SIA memiliki tingkat keamanan } \\
\text { dengan hanyak memberikan } \\
\text { izin akses kepada yang berhak }\end{array}$ & 0 & 2 & 67 & 16 & 3 & 3,23 & 284 \\
\hline & \multicolumn{1}{|c|}{} & & & & & & & \\
\hline
\end{tabular}

\section{Variabel Sarana Pendukung SIA}

Untuk mengetahui tanggapan responden terhadap variabel Sarana Pendukung Sistem Informasi Akuntansi untuk setiap item pertanyaan pada kuesioner penelitian dapat dilihat pada tabel sebagai berikut.

Tabel 4.4.

Tanggapan Responden untuk Variabel Sarana Pendukung SIA

\begin{tabular}{|c|c|c|c|c|c|c|c|c|}
\hline No & Pertanyaan & STS & TS & KS & S & SS & $\begin{array}{c}\text { Rata- } \\
\text { rata }\end{array}$ & $\begin{array}{c}\text { Total } \\
\text { Skor }\end{array}$ \\
\hline 1. & $\begin{array}{l}\text { Tersedia ruangan yang mema- } \\
\text { dai untuk menempatkan pera- } \\
\text { latan pendukung Sistem Infor- } \\
\text { masi Akuntansi }\end{array}$ & 0 & 0 & 36 & 42 & 11 & 3,72 & 327 \\
\hline 2. & $\begin{array}{l}\text { Tersedia perangkat komputer } \\
\text { yang layak dan sesuai untuk } \\
\text { digunakan }\end{array}$ & 0 & 0 & 24 & 35 & 29 & 4,06 & 357 \\
\hline 3. & $\begin{array}{l}\text { Tersedia jaringan berbagi ber- } \\
\text { sama (online) untuk mendu- } \\
\text { kung kinerja SIA di perusahaan }\end{array}$ & 0 & 0 & 7 & 32 & 49 & 4,48 & 394 \\
\hline & & & & & & & & 1078 \\
\hline
\end{tabular}

Sumber: Data Diolah, 2019

\section{Variabel Kinerja Perusahaan}

Untuk mengetahui tanggapan responden terhadap variabel Kinerja Perusahaan untuk setiap item pertanyaan pada kuesioner penelitian dapat dilihat pada tabel sebagai berikut. 
Tabel 4.5.

Tanggapan Responden untuk Variabel Kinerja Perusahaan

\begin{tabular}{|c|c|c|c|c|c|c|c|c|}
\hline No & Pertanyaan & STS & TS & KS & $\mathbf{S}$ & SS & $\begin{array}{c}\text { Rata- } \\
\text { rata }\end{array}$ & $\begin{array}{l}\text { Total } \\
\text { Skor }\end{array}$ \\
\hline (1) & (2) & (3) & (4) & (5) & (6) & (7) & (8) & (9) \\
\hline 1. & $\begin{array}{l}\text { Penerapan Sistem Informasi } \\
\text { Akuntansi dapat memudahkan } \\
\text { perencanaan kebijakan ke depan } \\
\text { bagi perusahaan }\end{array}$ & 0 & 0 & 28 & 53 & 7 & 3,76 & 331 \\
\hline 2. & $\begin{array}{l}\text { Melalui penerapan SIA dapat } \\
\text { memudahkan penyidikan dan } \\
\text { investigasi dari setiap laporan } \\
\text { perusahaan }\end{array}$ & 0 & 0 & 34 & 37 & 17 & 3,81 & 335 \\
\hline 3. & $\begin{array}{l}\text { Sistem Informasi } \text { Akuntansi } \\
\text { dapat meningkatkan koordinasi } \\
\text { di setiap bidang pelaporan peru- } \\
\text { sahaan }\end{array}$ & 0 & 0 & 32 & 38 & 18 & 3,84 & 338 \\
\hline 4. & $\begin{array}{l}\text { Hasil penyajian laporan peru- } \\
\text { sahaan melalui penerapan SIA } \\
\text { dapat dievaluasi setiap saat se- } \\
\text { suai dengan kebutuhan perusa- } \\
\text { haan }\end{array}$ & 0 & 0 & 30 & 39 & 19 & 3,88 & 341 \\
\hline 5. & $\begin{array}{l}\text { Penerapan Sistem Informasi } \\
\text { Akuntansi dapat memudahkan } \\
\text { pengawasan terhadap pelaporan } \\
\text { perusahaan }\end{array}$ & 0 & 0 & 21 & 38 & 29 & 4,09 & 360 \\
\hline 6. & $\begin{array}{l}\text { Dari hasil penyajian laporan } \\
\text { perusahaan melalui SIA dapat } \\
\text { membantu pihak manajerial da- } \\
\text { lam memaksimalkan tugas po- } \\
\text { kok dan fungsi dari setiap staf } \\
\text { sesuai dengan bidangnya ma- } \\
\text { sing-masing }\end{array}$ & 0 & 0 & 26 & 49 & 13 & 3,85 & 339 \\
\hline (1) & $(2)$ & (3) & (4) & (5) & (6) & (7) & (8) & (9) \\
\hline 7. & $\begin{array}{l}\text { Hasil penyajian laporan peru- } \\
\text { sahaan melalui SIA dapat } \\
\text { mempercepat proses penyajian } \\
\text { laporan perusahaan }\end{array}$ & 0 & 0 & 18 & 44 & 26 & 4,09 & 360 \\
\hline 8. & $\begin{array}{l}\text { Sistem Informasi Akuntansi } \\
\text { dapat menyajikan laporan yang } \\
\text { efektif sesuai dengan target yang }\end{array}$ & 0 & 0 & 25 & 44 & 19 & 3,93 & 346 \\
\hline
\end{tabular}

\section{Pengujian Instrumen Penelitian}

\section{Uji Validitas}

Uji validitas dilakukan dengan menggunakan Pearson Product-Moment Coeficient of Correlation. Dari tabel $\mathrm{r}$ product-moment untuk $\mathrm{N}=88$ pada taraf signifikansi $5 \%(\alpha=0,05)$ diperoleh nilai kritis yaitu $0,207$.

Hasil pengujian validitas data menunjukkan bahwa koefisien korelasi yang diperoleh oleh masingmasing item dari variabel Penerapan Sistem Informasi Akuntansi yang meliputi: Pemanfaatan SIA (X1), Kualitas SIA (X2), Keamanan SIA $(X 3)$, Sarana Pendukung SIA $(X 4)$, dan variabel Kinerja Perusahaan $(Y)$ untuk setiap item pertanyaan yang berjumlah 27 item dinyatakan valid $100 \%$ karena nilai $r$ di atas nilai korelasi kritis momen produk (koefisien korelasi> $0,207)$, sehingga kuesioner yang digunakan dianggap valid.

\section{Hasil Uji Reliabilitas}

Pengujian reliabilitas juga dilakukan secara statistik dengan menghitung besarnya nilai Cronbach's Alpha seperti terlihat pada tabel berikut ini.

Tabel 4.11.

Hasil Uji Realibilitas

\begin{tabular}{|c|l|c|c|c|}
\hline No & \multicolumn{1}{|c|}{ Variabel } & $\begin{array}{c}\text { Jumlah } \\
\text { Item }\end{array}$ & $\begin{array}{c}\text { Nilai } \\
\text { Alpha }\end{array}$ & Keterangan \\
\hline 1. & Pemanfaatan SIA & 4 & 0,623 & Handal \\
2. & Kualitas SIA & 8 & 0,741 & Handal \\
3. & Keamanan SIA & 4 & 0,784 & Handal \\
& Sarana Pendukung SIA & 3 & 0,896 & Handal \\
& Kinerja Perusahaan & 8 & 0,747 & Handal \\
\hline
\end{tabular}

Sumber: Data Diolah, 2019

Dari data hasil uji reliabilitas pada tabel di atas menunjukkan bahwa instrumen dalam penelitian ini handal (reliable) karena nilai Cronbach's Alpha untuk masing-masing variabel lebih besar dari 0.6, sehingga dapat disimpulkan bahwa kuesioner yang dijadikan alat ukur dalam penelitian ini layak untuk digunakan sebagai alat pengumpul data. (Sekaran, 2012:182)

Berdasarkan hasil output komputer melalui program SPSS dari nilai coefficients ${ }^{a}$ di atas, maka persamaan regresi berganda diperoleh sebagai berikut:

$$
Y=0,705+1,266 X_{1}+0,190 X_{2}+0,360 X_{3}+
$$
$0,158 X_{3}$

Dari persamaan dan hasil output di atas dapat diketahui hasil-hasil penelitian sebagai berikut:

1. Koefisien korelasi (R) sebesar 0,990 menunjukkan bahwa derajat hubungan (korelasi) antara variabel pemanfaatan SIA, kualitas SIA, keamanan SIA, dan sarana pendukung SIA terhadap kinerja perusahaan sebesar $99,0 \%$.

2. Koefisien regresi $(\beta)$ :

a) Konstanta sebesar 0,705 artinya jika variabel pemanfaatan SIA, kualitas SIA, keamanan SIA, dan sarana pendukung SIA diabaikan, maka kinerja perusahaan adalah sebesar $70,5 \%$.

b) Koefisien regresi pemanfaatan SIA adalah sebesar 1,266 artinya setiap $100 \%$ peningkatan variabel kinerja perusahaan maka secara relatif akan mempengaruhi peningkatan terhadap pemanfaatan SIA sebesar 126,6\%.

c) Koefisien regresi kualitas SIA adalah sebesar 0,190 artinya setiap $100 \%$ peningkatan variabel kinerja perusahaan maka secara relatif akan mempengaruhi peningkatan terhadap kualitas SIA sebesar 19,0\%.

d) Koefisien regresi keamanan SIA adalah sebesar 0,360 artinya setiap $100 \%$ peningkatan 
variabel kinerja perusahaan maka secara relatif akan mempengaruhi peningkatan terhadap keamanan SIA sebesar 36,0\%.

e) Koefisien regresi sarana pendukung SIA adalah sebesar 0,158 artinya setiap $100 \%$ peningkatan variabel kinerja perusahaan maka secara relatif akan mempengaruhi peningkatan terhadap sarana pendukung SIA sebesar $15,8 \%$.

Dengan menggunakan uji-t, Anda dapat menentukan apakah variabel independen memiliki pengaruh signifikan terhadap variabel dependen, sedangkan uji-F digunakan untuk secara simultan menentukan pengaruh variabel independen terhadap variabel dependen.

Berdasarkan ketentuan pengujian yang menyebutkan jika nilai sig $>\alpha(0,05)$ atau $t_{\text {hitung }}<t_{\text {tanel }}$ maka hipotesis penelitian ditolak, dan jika sig $<\alpha$ $(0,05)$ atau $t_{\text {hitung }}>t_{\text {tabel }}$ maka hipotesis penelitian diterima. Dari tabel di atas dapat disimpulkan bahwa:

1) Untuk uji parsial pemanfaatan SIA $\left(X_{1}\right)$ terhadap kinerja perusahaan $(Y)$, diketahui nilai sig $=0,000$ dan $t_{\text {hitung }}=12,772$. Dengan kata lain nilai sig < 0,05 atau $t_{\text {hitung }}>t_{\text {tabel }}$ dimana $t_{\text {tabel }}=1,987$, jadi hipotesis penelitian $\mathrm{Ha}_{2}$ yang menyatakan bahwa "Pemanfaatan Sistem Informasi Akuntansi (SIA) berpengaruh signifikan terhadap kinerja perusahaan" dapat diterima dan $\mathrm{Ho}_{2}$ ditolak.

2) Untuk uji parsial kualitas SIA $\left(X_{2}\right)$ terhadap kinerja perusahaan $(Y)$, diketahui nilai sig $=0,000$ dan $\mathrm{t}_{\text {hitung }}=4,124$. Dengan kata lain nilai sig $<0,05$ atau $t_{\text {hitung }}>t_{\text {tabel }}$ dimana $t_{\text {tabel }}=1,987$, jadi hipotesis penelitian $\mathrm{Ha}_{3}$ yang menyatakan bahwa "Kualitas Sistem Informasi Akuntansi (SIA) berpengaruh signifikan terhadap kinerja perusahaan" dapat diterima dan $\mathrm{Ho}_{3}$ ditolak.

3) Untuk uji parsial keamanan SIA $\left(X_{3}\right)$ terhadap kinerja perusahaan $(Y)$, diketahui nilai sig $=0,000$ dan $\mathrm{t}_{\text {hitung }}=3,932$. Dengan kata lain nilai sig $<0,05$ atau $t_{\text {hitung }}>t_{\text {tabel }}$ dimana $t_{\text {tabel }}=1,987$, jadi hipotesis penelitian $\mathrm{Ha}_{4}$ yang menyatakan bahwa "Keamanan Sistem Informasi Akuntansi (SIA) berpengaruh signifikan terhadap kinerja perusahaan" dapat diterima dan $\mathrm{Ho}_{4}$ ditolak.

4) Untuk uji parsial sarana pendukung SIA $\left(X_{4}\right)$ terhadap kinerja perusahaan $(Y)$, diketahui nilai sig $=0,006$ dan $t_{\text {hitung }}=2,848$. Dengan kata lain nilai sig $<0,05$ atau $t_{\text {hitung }}>t_{\text {tabel }}$ dimana $t_{\text {tabel }}=1,987$, jadi hipotesis penelitian $\mathrm{Ha}_{5}$ yang menyatakan bahwa "Sarana Pendukung Sistem Informasi Akuntansi (SIA) berpengaruh signifikan terhadap kinerja perusahaan" dapat diterima dan $\mathrm{Ho}_{5}$ ditolak.

5) Untuk uji simultan antara Pemanfaatan SIA $\left(X_{1}\right)$, Kualitas SIA $\left(X_{2}\right)$, Keamanan SIA $\left(X_{3}\right)$, dan Sarana Pendukung SIA $\left(X_{4}\right)$ terhadap Kinerja Perusahaan $(Y)$, diketahui nilai sig $=0,001$ dan $\mathrm{F}_{\text {hitung }}=$ 105,310. Dengan kata lain nilai sig $<0,05$ atau $F_{\text {hitung }}>F_{\text {tabel }}$ dimana $F_{\text {tabel }}=2,48$, jadi hipotesis penelitian $\mathrm{Ha}_{1}$ yang menyatakan bahwa "Pemanfaatan, Kualitas, Keamanan dan Sarana Pendukung Sistem Informasi Akuntansi (SIA) secara bersama-sama berpengaruh signifikan terhadap kinerja perusahaan" dapat diterima dan $\mathrm{Ho}_{1}$ ditolak.

\section{Pembahasan \\ Pengaruh Pemanfaatan SIA Terhadap Kinerja Perusahaan}

Untuk uji parsial pemanfaatan SIA $\left(X_{l}\right)$ terhadap kinerja perusahaan $(Y)$, diketahui nilai sig $=0,000$ dan $\mathrm{t}_{\text {hitung }}=12,772$. Dengan kata lain nilai sig $<0,05$ atau $t_{\text {hitung }}>t_{\text {tabel }}$ dimana $t_{\text {tabel }}=1,987$, jadi hipotesis penelitian $\mathrm{Ha}_{2}$ yang menyatakan bahwa "Pemanfaatan Sistem Informasi Akuntansi (SIA) berpengaruh signifikan terhadap kinerja perusahaan" dapat diterima dan $\mathrm{Ho}_{2}$ ditolak.

Ini sesuai dengan hasil penelitian yang dilakukan oleh Periyanti \& Effendi (2014), Diketahui bahwa penggunaan sistem informasi akuntansi dengan karakteristik yang relevan, dapat diandalkan, lengkap dan tepat waktu memiliki dampak signifikan terhadap efisiensi manajemen. selanjutnya, menurut Hall (2009) Penggunaan sistem informasi akuntansi dapat dilakukan berdasarkan jenis aktivitas perusahaan, yang dibagi menjadi beberapa subsistem sistem informasi akuntansi, yaitu: (1) Sistem pemrosesan transaksi (Transaction Processing System-TPS); (2) Sistem buku besar atau pelaporan keuangan (General ledger or Financial Reporting System-GL/FRS); dan (3) Sistem pelaporan manajemen (Management Reporting System-MRS)

Penggunaan teknologi informasi yang tepat terkait dengan penggunaan sistem informasi akuntansi untuk perusahaan dapat meningkatkan produktivitas 
perusahaan. Hasil yang dapat diperoleh dengan menggunakan sistem informasi akuntansi adalah informasi. Informasi adalah data yang telah dipesan dan diproses agar masuk akal (Romney \& Steinbart, 2011).

Penggunaan sistem informasi akuntansi dapat dilihat dari keberadaan komputer, perangkat lunak dan jaringan internet. Proses akuntansi dapat didukung menggunakan perangkat lunak akuntansi yang tersedia di komputer perusahaan (Widyaningtyas, 2013). Ini adalah komponen awal untuk menerapkan sistem informasi akuntansi terkomputerisasi dalam suatu perusahaan. Kemudian, dengan bantuan komputer, perangkat lunak dan Internet, proses akuntansi seperti proses transaksi dan akuntansi persediaan dilakukan.

\section{Pengaruh Kualitas SIA Terhadap Kinerja Perusahaan}

Untuk uji parsial kualitas SIA $\left(X_{2}\right)$ terhadap kinerja perusahaan $(Y)$, diketahui nilai sig $=0,000$ dan $\mathrm{t}_{\text {hitung }}=4,124$. Dengan kata lain nilai sig $<0,05$ atau $t_{\text {hitung }}>t_{\text {tabel }}$ dimana $t_{\text {tabel }}=1,987$, jadi hipotesis penelitian $\mathrm{Ha}_{3}$ yang menyatakan bahwa "Kualitas Sistem Informasi Akuntansi (SIA) berpengaruh signifikan terhadap kinerja perusahaan" dapat diterima dan $\mathrm{Ho}_{3}$ ditolak.

Hasil penelitian tersebut sejalan dengan dengan hasil penelitian yang dilakukan oleh Harash (2002) yang menjelaskan bahwa kualitas SIA sangat menentukan terhadap validitas laporan perusahaan dan tentunya berdampak positif terhadap kinerja perusahaan yang dalam hal ini adalah UMKM.

Variabel kualitas sistem informasi akuntansi berasal dari pengukuran yang terdapat dalam model keberhasilan sistem informasi D \& M. Kualitas sistem dan kualitas informasi yang diterima akan menentukan bagaimana pengguna menggunakan dan memenuhi penerapan sistem informasi akuntansi di perusahaan. Maka itu akan mempengaruhi kinerja orang tersebut, dan selanjutnya akan mempengaruhi kinerja perusahaan (Jones \& Dasaratha, 2008).

Kualitas sistem informasi akuntansi mengacu pada kualitas perangkat lunak yang digunakan di perusahaan. Memiliki perangkat lunak yang andal dapat menyederhanakan proses akuntansi sebagai tambahan untuk menggunakan komputer. Beberapa kriteria perangkat lunak yang dapat digunakan dalam suatu perusahaan mudah dipahami dan dapat meningkatkan relevansi, akurasi, singkatnya, kelengkapan dan ketepatan waktu laporan perusahaan (Romney, 2012).

\section{Pengaruh Keamanan SIA Terhadap Kinerja Perusahaan}

Untuk uji parsial keamanan SIA $\left(X_{3}\right)$ terhadap kinerja perusahaan $(Y)$, diketahui nilai sig $=0,000$ dan $\mathrm{t}_{\text {hitung }}=3,932$. Dengan kata lain nilai sig $<0,05$ atau $t_{\text {hitung }}>t_{\text {tabel }}$ dimana $t_{\text {tabel }}=1,987$, jadi hipotesis penelitian $\mathrm{Ha}_{4}$ yang menyatakan bahwa "Keamanan Sistem Informasi Akuntansi (SIA) berpengaruh signifikan terhadap kinerja perusahaan" dapat diterima dan $\mathrm{Ho}_{4}$ ditolak.

Titisari (2015) mengatakan teknologi yang baik dan dapat diandalkan dianggap aman bagi penggunanya. Keamanan sistem adalah bagian dari sistem kualitas, yang akan mempengaruhi kepuasan pengguna dengan sistem informasi akuntansi. Sistem informasi akuntansi keamanan akan mempengaruhi data yang terkandung dalam informasi yang dihasilkan. Dengan demikian, kualitas informasi menjadi diragukan jika tidak ada perlindungan dalam sistem informasi akuntansi.

Dengan adanya sistem yang semi-otomatis sudah sangat membantu manajerial dalam mempertimbangkan kebutuhan laporan keuangan yang memadai walaupun tidak akuntabel dan efektif sebagai sarana untuk membantu pengambilan kebijakan. Sistem informasi yang baik tentunya didukung oleh tingkat keamanan yang handal dan mencegah dari adanya kerusakan fisik maupun non-fisik terhadap data perusahaan sehingga berpengaruh positif terhadap laporan yang dihasilkan yang berdampak kepada peningkatan efisiensi dan kinerja perusahaan dalam menyiapkan laporan keuangan maupun non-keuangan.

\section{Pengaruh Sarana Pendukung SIA Terhadap Kinerja Perusahaan}

Hasil uji parsial sarana pendukung SIA $\left(X_{4}\right)$ terhadap kinerja perusahaan $(Y)$, diketahui nilai sig $=$ 0,006 dan $t_{\text {hitung }}=2,848$. Dengan kata lain nilai sig < 0,05 atau $t_{\text {hitung }}>t_{\text {tabel }}$ dimana $t_{\text {tabel }}=1,987$, jadi hipotesis penelitian $\mathrm{Ha}_{5}$ yang menyatakan bahwa "Sarana Pendukung Sistem Informasi Akuntansi (SIA) berpengaruh signifikan terhadap kinerja perusahaan" dapat diterima dan $\mathrm{Ho}_{5}$ ditolak. 
Diharapkan bahwa sistem informasi akuntansi akan dapat memberikan informasi keuangan atau nonkeuangan secara akurat dan tepat waktu. Untuk meningkatkan manfaat dari penggunaan sistem informasi akuntansi, alat bantu tambahan digunakan (Titisari, 2015). Diyakini bahwa alat pendukung sistem akuntansi informasi penting untuk meningkatkan efisiensi sistem akuntansi informasi. Diharapkan, dengan dukungan sistem informasi akuntansi, sistem informasi akuntansi dapat memberikan manfaat optimal bagi perusahaan.

Beberapa perusahaan tidak menggunakan komputer dan sistem komputer. Ini dapat dilakukan oleh komputer dan perangkat lunak dalam kategori alat bantu dalam penerapan sistem informasi akuntansi. Kehadiran lingkungan kerja yang nyaman juga dapat mempengaruhi efisiensi penggunaan sistem akuntansi informasi. Salah satu contoh adalah ketersediaan ruang yang cukup untuk sistem, serta kenyamanan dan ketepatan ruangan, yang dapat memberikan motivasi atau antusiasme tambahan bagi pekerjaan karyawan untuk meningkatkan pekerjaan mereka (Titisari, 2015).

Kinerja perusahaan merupakan hasil dari pemanfaatan secara baik atas sumber daya yang ada dan sekaligus mencerminkan seberapa jauh sebuah keberhasilan tercapai atau hasil kerja secara kuantitas dan kualitas yang dicapai oleh seorang manajer dalam melaksanakan tugasnya sesuai tanggung jawab yang diberikan kepadanya.

Keberadaan sarana pendukung tentunya masih banyak UMKM yang tidak terlalu mempertimbangkan dan menganggap layaknya kebutuhan biasa yang cukup sesuai kebutuhan tanpa perlu menganggap pentingnya sarana pendukung yang layak. Misalnya saja cukup dengan ketersediaan komputer yang layak dan terkoneksi dengan internet tanpa harus menyediakan ruangan khusus yang cukup nyaman dan aman bagi dukungan perangkat. Hal ini dapat dilihat bahwa sejumlah UMKM tersebut masih menyewa toko atau rumah sekedarnya dan menjadikannya sebagai kantor tempat bagian manajemen bekerja. Sasaran penting sarana pendukung dapat mempengaruhi kinerja dengan dukungan teknis maupun non-teknis dalam upaya memaksimalkan keberadaan Sistem Informasi Akuntansi bagi perusahaan.

\section{Kesimpulan dan Saran}

Setelah dilakukan pengujian dan analisis data dalam penelitian ini, maka dapat disimpulkan bahwa:

1) Pemanfaatan, Kualitas, Keamanan dan Sarana Pendukung Sistem Informasi Akuntansi (SIA) secara bersama-sama berpengaruh signifikan terhadap kinerja perusahaan.

2) Pemanfaatan, Kualitas, Keamanan dan Sarana Pendukung Sistem Informasi Akuntansi (SIA) secara bersama-sama berpengaruh signifikan terhadap kinerja perusahaan.

3) Kualitas Sistem Informasi Akuntansi (SIA) berpengaruh signifikan terhadap kinerja perusahaan.

4) Keamanan Sistem Informasi Akuntansi (SIA) berpengaruh signifikan terhadap kinerja perusahaan.

5) Sarana Pendukung Sistem Informasi Akuntansi (SIA) berpengaruh signifikan terhadap kinerja perusahaan.

Berdasarkan hasil penelitian, kesimpulan yang telah diuraikan sebelumnya, maka peneliti memberikan beberapa saran sebagai berikut:

1) Diperlukan penelitian lanjutan untuk dapat mengukur variabel yang berhubungan dengan penerapan SIA pada UMKM mengingat masih banyaknya UMKM yang belum menerapkan SIA.

2) Penulisan ini diharapkan dapat dijadikan salah satu acuan dalam mengkaji eksistensi UMKM yang ada di Banda Aceh dalam penerapan SIA

3) Sebaiknya penelitian ditujukan kepada UMKM dengan aspek dan jenis usaha yang seragam misalnya, usaha perdagangan, usaha industri ataupun usaha penyediaan jasa.

\section{Daftar Pustaka}

Arikunto, Suharsimi. (2010). Prosedur Penelitian Suatu Pendekatan Praktek. Jakarta: PT. Rineka Cipta.

Baridwan, Zaki. (2015). Sistem Akuntansi. Yogyakarta: BPTE

Gelinas. U.J, Dull, R.B. \& Wheeler, P.R. (2012). Accounting Information System 9th Edition. USA: South-Western Cengage Learning.

George. (2013). Akuntansi Pengantar. Jakarta: FE UI

Hall, A. James. (2002). Sistem Informasi Akuntansi 2. Edisi ke-1. Jakarta: Salemba Empat. 
Hall, James A. (2013). Sistem Informasi Akuntansi. Jakarta: Salemba Empat

Hansen \& Mowen. (2006). Akuntansi Manajemen. Edisi ke-4. Jakarta: Selemba Empat.

Ikatan Akuntan Indonesia. (2002). Standar Akuntansi Keuangan. Edisi Revisi. Jakarta: Salemba Empat.

James A, O'Brien,. (2013). Introduction to Information Systems, Terjemahan oleh Dewi Fitriasari. Jakarta: Salemba Empat.

Jones, Frederick L. \& Dasaratha, Rama. (2008). Sistem Informasi Akuntansi. (Edisi Pertama). Terjemahan M. Slamet Wibowo. Jakarta: Salemba Empat.

Kaplan \& Norton. (2001). The Strategy Focused Organization, How Balanced Scorecard Company Thrive in The New Business Environment Harvard. Boston: Business Press.

Kaplan \& Norton. (2006). The Balanced Scorecard, Translating Strategy into Action. Boston:Harvard Business Press.

Laudon, Kenneh C., \& Jane P. Laudon. (2000). Organization and Technology in the Networked Enterprise. Management Information System. Six Edition.

Mulyadi. (2010). Sistem Akuntansi. Edisi ke-3. Jakarta: Selemba Empat.

Mulyadi. (2010). Sistem Akuntansi. Yogyakarta: STIE YKPN

Onaolapo A.A., and Odetayo T.A. 2012. Effect of Accounting Information System on Organi sational Effectiveness. American Journal of Business and Management, 1 (4)., pp: 183-189.

Otley, D. T. (2008). The Contingency Theory of Management Accounting: Achievement and Prognosis. The Journal of Accounting Organization \& Society. Vol.5. pp 413-428.

Romney \& Steinhart. (2006). Sistem Informasi Akuntansi I. Edisi ke-9. Jakarta: Selemba Empat.

Romney B., Marshall \& Paul J. Steinbart. (2012). Sistem Informasi Akuntansi, Edisi Kesembilan, Terjemahan Dewi Fitriasari \& Deny Amos Kwary. Jakarta: Salemba Empat.

Satzinger, J.W., Jackson,R.B. \& Burd, S.D. (2011). Systems Analysis and Design in a Changing World (Sixth Edition). USA: Cengage Learning

Sekaran, U. (2006). Metode Penelitian Untuk Bisnis 1. (4th Ed). Jakarta: Salemba Empat.

Stair, Ralph M., dan Reynolds, George W. (2011). Fundamentals of Information Systems (With Access Code). USA: Cengage Learning. 